... Lunguleasa, Ayrilmis, Spirchez, Özdemir: Investigation of the Effects of Heat Treatment ...

Aurel Lunguleasa ${ }^{1}$, Nadir Ayrilmis ${ }^{2}$, Cosmin Spirchez ${ }^{1}$, Ferhat Özdemir ${ }^{3}$

\title{
Investigation of the Effects of Heat Treatment Applied to Beech Plywood
}

\section{Istraživanje utjecaja toplinske obrade na svojstva uslojene ploče od bukovine}

\author{
Original scientific paper • Izvorni znanstveni rad \\ Received-prispjelo: 26. 11. 2017. \\ Accepted-prihvaćeno: 27. 11. 2018. \\ UDK: $630 * 812.71 ; 630 * 832.282 ; 630 * 847.3$ \\ doi:10.5552/drind.2018.1768
}

\begin{abstract}
The aim of this study is to determine the effects of heat treatment on some physical and mechanical properties of beech plywood boards. The 3-layered beech plywood boards with a thickness of $3.9 \mathrm{~mm}$ were subjected to heat treatment for 1, 2 and 3 hours at temperatures of 160, 180 and $200{ }^{\circ} \mathrm{C}$. These beech plywood boards were tested for physical properties such as density, water absorption and thickness swelling, mechanical property tests such as modulus of rupture (MOR) and Brinell hardness, and mass loss rates according to the relevant standards. The results obtained show that the hydrophobicity of beech plywood boards is improved but the strength and weight loss are adversely affected, depending on the temperature and duration of heat treatment. It has been found that beech plywood boards heat-treated at $200{ }^{\circ} \mathrm{C}$ for 3 hours can be used in very humid environments for average mechanical stresses of wood parts with a reduced thickness swell of $4 \%$ and a reduced water absorption rate of more than $12 \%$.
\end{abstract}

Keywords: plywood, heat treatment, mass loss, swelling, Brinell hardness, water absorption

SAŽETAK • Cilj istraživanja bio je utvrditi utjecaj toplinske obrade na neka fizička i mehanička svojstva uslojenih ploča od bukovine. Troslojne uslojene ploče od bukovine debljine 3,9 mm podvrgnute su toplinskoj obradi u trajanju jednoga, dva i tri sata pri temperaturama 160, 180 i $200{ }^{\circ}$ C. Prema odgovarajućim standardima, ispitana su fizička svojstva tih ploča kao što su gustoća, apsorpcije vode i bubrenje, mehanička svojstva poput modula loma (MOR) i tvrdoće prema Brinellu te gubitka mase. Dobiveni su rezultati pokazali da se hidrofobnost ploča povećala, ali je njihova toplinska obrada negativno utjecala na čvrstoću i gubitak mase ovisno o trajanju $i$ temperaturi obrade. Utvrđeno je da se uslojene ploče od bukovine, toplinski obrađene pri temperaturi od $200{ }^{\circ} \mathrm{C}$ u trajanju tri sata, mogu upotrebljavati u vrlo vlažnim uvjetima, pri prosječnome mehaničkom opterećenju drvnih dijelova, uz smanjenje bubrenja od $4 \%$ i smanjenje apsorpcije vode veće od $12 \%$.

Ključne riječi: uslojeno drvo, toplinska obrada, gubitak mase, bubrenje, tvrdoća prema Brinellu, apsorpcija vode

\footnotetext{
${ }^{1}$ Authors are professor and PhD student at Department of Wood Processing and Design of Wooden Products, Faculty of Wood Engineering, Transylvania University of Brasov, Brasov, Romania. ${ }^{2}$ Author is professor at Department of Wood Science, Section of Mechanical Wood Composite Technology, Faculty of Forestry, Istanbul University-Cerrahpasa, Istanbul, Turkey. ${ }^{3}$ Author is assistant professor at Department of Forest Industry Engineering, Faculty of Forestry, Kahramanmaras Sutcu Imam University, Kahramanmaras, Turkey.

Autori su profesor i doktorand Odsjeka za obradu drva i dizajn drvnih proizvoda, Fakultet drvne industrije, Transilvanijsko sveučilište Brašov, Brašov, Rumunjska. ${ }^{2}$ Autor je profesor Odsjeka za znanost o drvu, Zavod za mehaničku obradu drvnih kompozita, Šumarski fakultet, Sveučilište u Istanbulu-Cerrahpasa, Istanbul, Turska. ${ }^{3}$ Autor je izvanredni profesor Odsjeka za industriju na bazi šuma, Šumarski fakultet, Kahramanmaras Sutcu Imam Sveučilište, Kahramanmaras, Turska.
} 


\section{INTRODUCTION}

\section{UVOD}

Plywood is an ancient engineering product, known as a primary form since the times of the ancient Egyptians. It is made of three or more layers (usually an odd number) of veneer, disposed at $90^{\circ}$ between them, glued and pressed. The odd number of veneers is given by the symmetry of the final board structure, i.e. the existence of a median layer, next to which other veneer layers are placed on one side and the other. The perpendicular layout of two adjacent veneer layers confers to the board a high uniformity of the properties, especially of fibers perpendicular and parallel with the wood. Although recently these boards have been increasingly replaced by fiberboards in the furniture manufacturing industry, or by oriented strand boards in the field of construction, they are still products demanded for various other uses. Among the board properties that make them preferable to massive wood, the following can be mentioned: board density is slightly higher than the one of massive wood from which veneer was made, due to the densification degree and the density of the adhesive in dry state; board higroscopicity is low i.e. approximately 10 times lower transversally as compared to massive wood, due to the presence of dry adhesive (not hygroscopic); the board has higher strength than massive wood and the quality index (the ratio between strength and density) makes the board superior to steel and aluminum alloys. At the same time, the board is a homogeneous product and reduces the effect of the natural defects of massive wood, spreading them on wide surfaces.

The purpose of heat treatment of wooden products (lumber, shredding, sawdust and chips, briquettes, pellets, straw, rice husk) at high temperatures is to improve properties (Lundborg, 1998; Demirbas, 2001; Jehlickova and Morris, 2007; Gavrilescu, 2008; Chen et al., 2011; Wang et al., 2011; Chen et al., 2012; Omer, 2012; Vilcek, 2013; Chen et al., 2014) such as absorption and thickness swelling, natural durability (especially the strength against attacks of xylophages fungi), caloric power (Kastanaki and Vamvuka, 2005), all these thanks to the degradation of the hemicelluloses in the wood (Prasertsan and Sajakulnukit, 2006; Jehlickova and Morris, 2007; Shulga et al., 2008). The true revolution in the field of heat treatment started with the introduction of the European standard CEN/TS 15679 in 2007. The use of classic boards in outdoor environment involves the use of more expensive adhesives, or the increase of the paraffin or wax content, which increases considerably their price. These inconveniences can be avoided by heat treatment of the boards at high temperatures, taking care not to reduce drastically their strength. The question also arises whether it is adequate to subject the boards to heat treatment and then to glue them (Zdravković et al., 2013), or to apply heat treatment directly to the plywood. The opinions of the researchers in this respect are contradictory. The important fact is to provide an efficient manufacturing chain (as short as possible), lower costs and as many as pos- sible benefits (Uslu, 2008; Batidzirai et al., 2013). Feher et al. (2014) considers that it is simpler to apply heat treatment to the veneer. The heat treated board acquires a black color, the black degree depending on the intensity of the applied treatment. The darkening of the veneers and boards represents heat treatment deficiency (Tabarés et al., 2000; Thomson et al., 2005; Lovrić et al., 2014; Salca et al., 2016), but it does not reduce the quality of the products used in outdoor environment, as the wooden surface darkens anyway under the effects of bad weather. Due to heat degradation, all heat treated products have lower strength, regardless of whether these products are manufactured of wood glued veneers, or Laminated Veneer Lumber (Nazerian et al., 2011; Nazerian and Ghalehno, 2011). However, at the beginning of the heat treatment between 150 and $160{ }^{\circ} \mathrm{C}$, a part of the strength of heat treated products slightly increases, after which their strength is reduced with the intensification of the heat treatment (Percin et al., 2016). Some authors found that heat treatment affects the reduction of formaldehyde emission, especially in the case of poplar boards (Murata et al., 2013). Heat treatment has additional beneficial effects on veneers when it is combined with their pressing at the pressure of 2.7 MPa (Arruda and del Menezzi, 2016).

The main objective of this study is to obtain an optimal heat treatment of 3-layered beech plywood, in order to be used in outdoor environment. For this purpose, it is intended to increase the hydrophobicity of the boards i.e. to reduce their absorption and thickness swelling in the conditions in which the mechanical properties (modulus of rupture MOR for static bending and Brinell hardness) could remain constant or slightly decrease.

\section{MATERIALS AND METHODS} 2. MATERIJALI I METODE

3 layer beech (Fagus Sylvatica L.) plywood sheets with an average thickness of $3.9 \mathrm{~mm}$ were purchased from the local market. Samples with dimensions of $380 \times 380 \mathrm{~mm}$ have been cut from various parts of the boards (edge, middle or median) for heat treatment. The heat treatment of the board was performed in a laboratory stove without oxygen admission. The heat treatment applied to the test samples is shown in Table 1.

First, all the samples were conditioned at $23 \pm 2$ ${ }^{\circ} \mathrm{C}$ and $65 \pm 5 \%$ relative humidity until they reached a constant weight. The heat treatments shown in Table 1 were applied to the test samples and the weight loss amounts were determined. Then, some physical and mechanical properties of the test specimens were investigated. Mechanical properties such as MOR (EN 310 , 2000) and Brinell hardness (EN 1534, 2000) together with physical property tests such as density (EN 323, 1993), water absorption and thickness swelling (EN 317) tests were carried out according to the relevant standards. The tests were repeated 15 times per each test type and parameter. The relationship between the force and time applied in the Brinell 
Table 1 Experimental parameters of heat treatment applied to beech plywood

Tablica 1. Parametri istraživanja toplinske obrade uslojene ploče od bukovine

\begin{tabular}{|c|c|c|c|c|}
\hline \multirow{2}{*}{$\begin{array}{c}\text { Board type } \\
\text { Vrsta ploče }\end{array}$} & \multicolumn{3}{|c|}{$\begin{array}{c}\text { Temperature, } \\
\text { Temperatura, }\end{array}$} \\
\cline { 3 - 5 } & & 160 & 180 & 200 \\
\hline \multirow{2}{*}{$\begin{array}{l}\text { Beech plywood (3.9 } \\
\text { mm) / uslojena ploča } \\
\text { od bukovine (3,9 mm) }\end{array}$} & Time, $\mathrm{h}$ & 1 & 1 & 1 \\
\cline { 3 - 5 } & & 0 & 0 & 0 \\
\cline { 3 - 5 } & & 3 & 2 & 2 \\
\cline { 3 - 5 } & & 3 & 3 \\
\hline
\end{tabular}

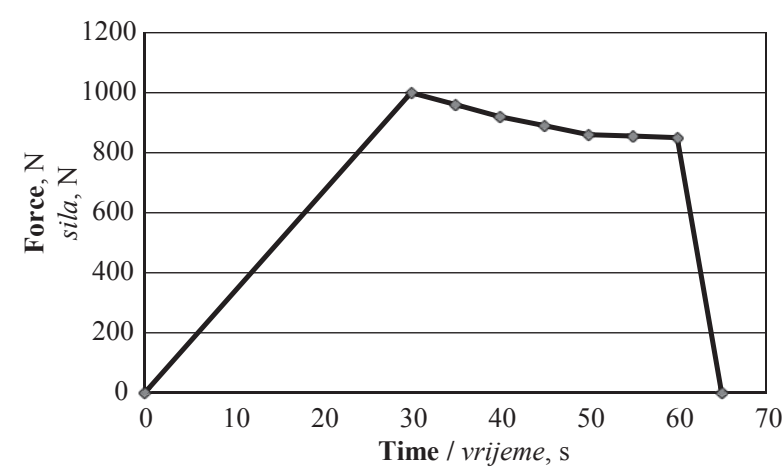

Figure 1 Force evolution in time of Brinell hardness testing Slika 1. Promjena sile tijekom vremena pri ispitivanju tvrdoće prema Brinellu

hardness test is given in Figure 1. All data were processed by using Microsoft Excel with the application of a statistical analysis.

\section{RESULTS AND DISCUSSION 3. REZULTATI I RASPRAVA}

Following the laboratory determinations, the analyzed board (herein after referred to as control sam- ple) had a thickness of $3.84 \pm 0.11 \mathrm{~mm}$, an average moisture content of $6.5 \%$ and density of $749 \pm 12 \mathrm{~kg} /$ $\mathrm{m}^{3}$. After the heat treatment, each piece was visually checked and defect free samples were kept under study. The first analyzed parameter was mass loss, which linearly increased (by Pearson $R^{2}$ coefficients in majority over 0.99 ) with the increase of temperature and exposure time (Figure 2). Only at $160{ }^{\circ} \mathrm{C}$, the mass loss linear variation is less accurate with the Pearson coefficient of 0.896 . Maximum mass loss was $3.52 \%$ at a temperature of $160{ }^{\circ} \mathrm{C}, 5.32 \%$ at a temperature of 180 ${ }^{\circ} \mathrm{C}$ and $10.68 \%$ at a temperature of $200{ }^{\circ} \mathrm{C}$.

When the heat treatment is performed at a moisture content of $0 \%$ (by drying at $103{ }^{\circ} \mathrm{C}$ in a lab oven), the board thickness slightly shrinks by losing moisture content from 6.5 to $0 \%$, with slight values of $0.8-1.9$ $\%$. This shrinkage does not have a big influence on the heat treatment process, being known the reversible absorption-desorption process of the water in the wooden products and their dimensional changes.

During the heat treatment process, the board degrades generally by degradation of the wood veneers, but also by degradation of the adhesive and consequently also the veneer adhesion.

The mechanical property that shows the highest board degradation is MOR (Windeisen et al., 2009), while the board surface degradation is shown by Brinell (Uslu et al., 2008). The modulus of rupture (MOR) was reduced significantly, depending on the torrefaction degree, from the value of $152.9 \mathrm{~N} / \mathrm{mm}^{2}$ to the minimum value of $120.8 \mathrm{~N} / \mathrm{mm}^{2}$ (a reduction of $20.9 \%$ ) at the temperature of $160{ }^{\circ} \mathrm{C}$, to $108.6 \mathrm{~N} / \mathrm{mm}^{2}$ (a reduction of $28.9 \%$ ) at the temperature of $180{ }^{\circ} \mathrm{C}$ and to 66.3 $\mathrm{N} / \mathrm{mm}^{2}$ (a reduction of $56.6 \%$ ) at the temperature of $200{ }^{\circ} \mathrm{C}$ (Figure 3). Similar values of MOR have been found by other authors for the torrefaction of spruce massive wood (Beckta and Niemz, 2003) or beech and ash species (Windeisen et al., 2009).

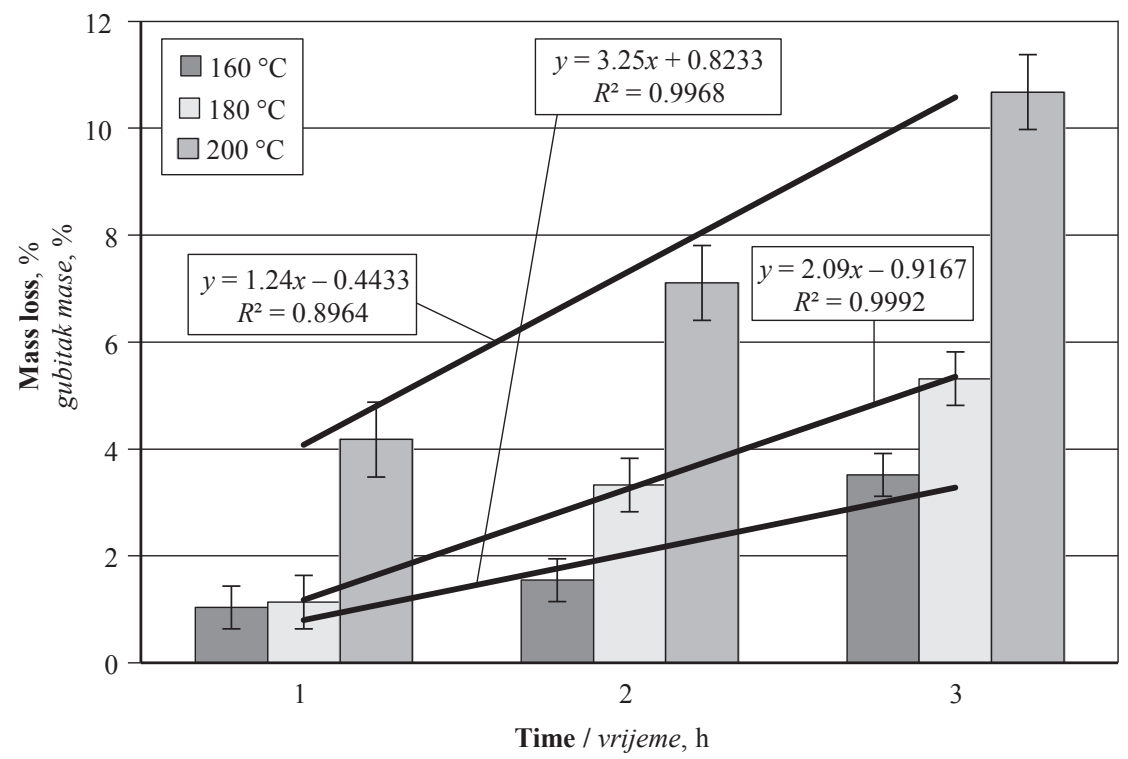

Figure 2 Influence of the heat treatment degree on mass loss

Slika 2. Utjecaj toplinske obrade na gubitak mase 


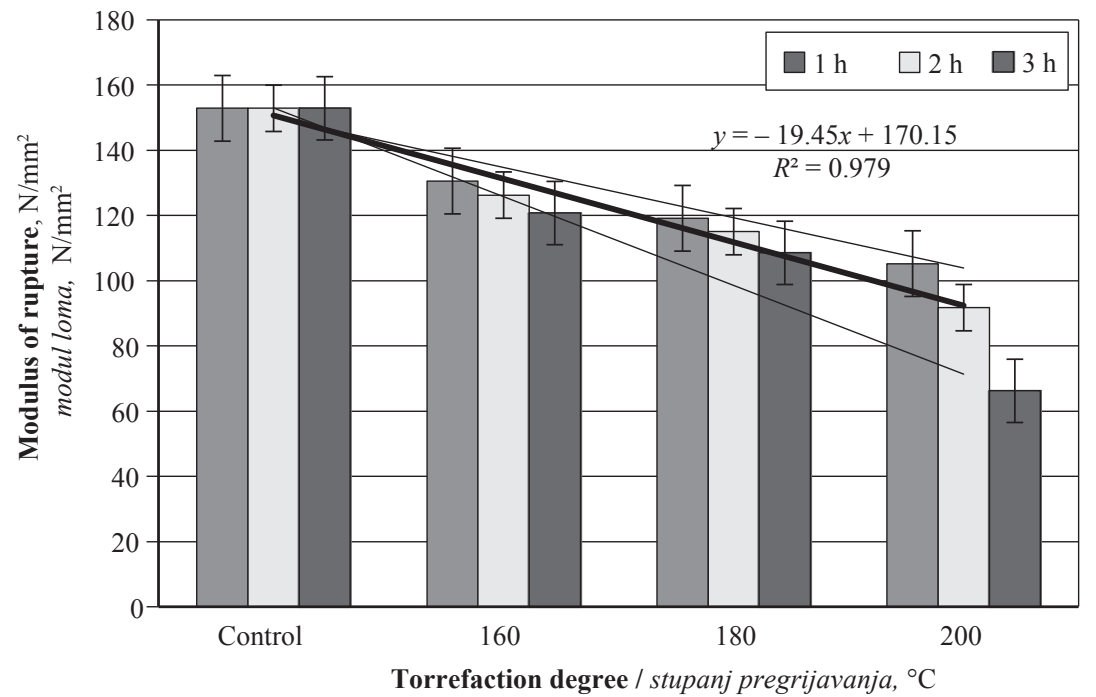

Figure 3 Influence of heat treatment degree on bending strength

Slika 3. Utjecaj toplinske obrade na čvrstoću na savijanje

Brinell hardness generally reduced depending on the treatment time, as well as depending on the heat treatment temperature (Figure 4). A slight increase in the Brinell hardness was found in the control sample $\left(44.3 \mathrm{~N} / \mathrm{mm}^{2}\right)$ as opposed to the sample treated at a temperature of $160{ }^{\circ} \mathrm{C}$ for 1 hour $\left(44.5 \mathrm{~N} / \mathrm{mm}^{2}\right)$, followed by its reduction of $8.1 \%$ at the same temperature and 3-hour treatment. The same phenomenon was previously noticed on heat treated MDF, which showed that some hardening of the wooden surface treated at the temperature of $160{ }^{\circ} \mathrm{C}$ for $1 \mathrm{~h}$ can be obtained, regardless of the type of composite material. The maximum reduction of the Brinell hardness was $16 \%$ at 180 ${ }^{\circ} \mathrm{C}$ and $40.6 \%$ at $200{ }^{\circ} \mathrm{C}$.

As shows in Figure 5, it was believed that the mass loss of the composite specimens was related to the decrease in Brinell hardness and tensile elastic modulus. Such trend confirmed that the mass loss increase leads to a proportional reduction of Brinell hardness and that it is almost proportional with the strength modulus to static bending. At the same time, a significant reduction of the MOR in the first phase of the heat treatment at $160{ }^{\circ} \mathrm{C}$ was noticed as well. Similar results were obtained for the treatment repeated at $180^{\circ} \mathrm{C}$ and $200{ }^{\circ} \mathrm{C}$.

The absorption and thickness swelling of the boards were significantly lower than those of the control samples (Figure 6). After 2 hours of immersion, water absorption was reduced from $33.8 \%$ for the control samples to $25.5 \%$ for the $180 / 3$ treatment degree, which represents a value reduction of $8.3 \%$ or a percentage reduction of $24.5 \%$. The corresponding thickness swelling was reduced from $6.9 \%$ to $3.1 \%$, namely a value reduction of $3.8 \%$ or a percentage reduction of $55.07 \%$. As expected, the highest reductions were obtained for the maximum treatment degree 200/3, with a value of over $70 \%$ of absorption and over $60 \%$ of swelling.

Thickness swelling showed the same decreasing trend as water absorption (Figure 6), i.e. it reduced by

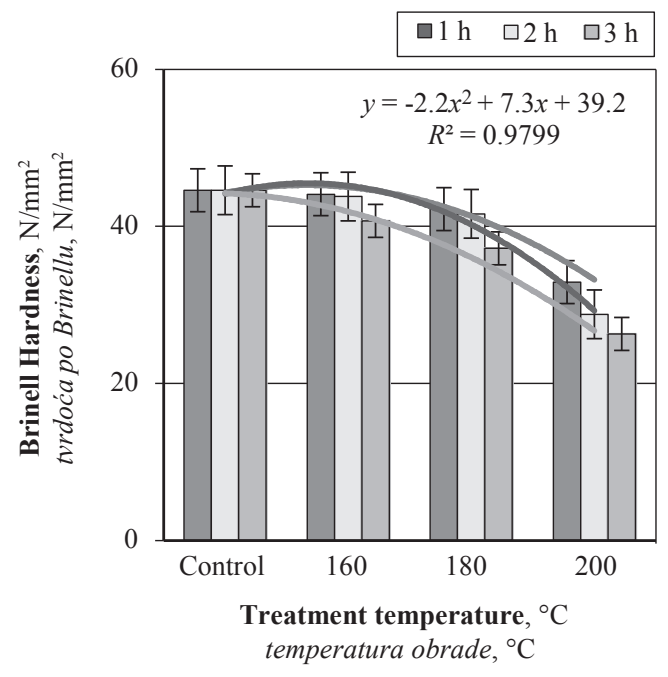

a)

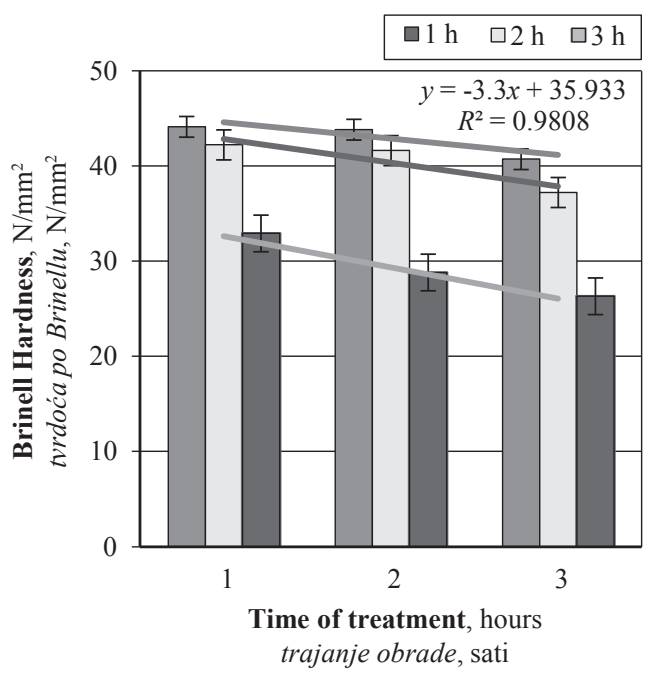

b)

Figure 4 Influence of heat treatment degree by temperature (a) and treatment time (b) on Brinell hardness

Slika 4. Utjecaj temperature (a) i trajanja (b) toplinske obrade na tvrdoću prema Brinellu 
... Lunguleasa, Ayrilmis, Spirchez, Özdemir: Investigation of the Effects of Heat Treatment ...

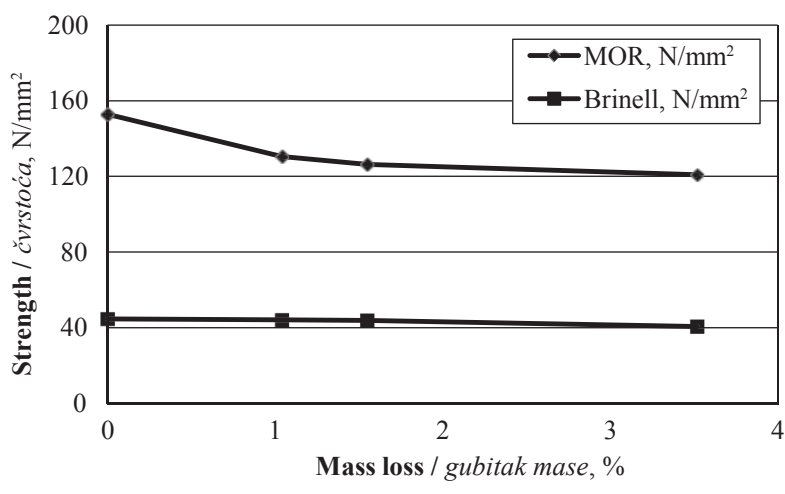

Figure 5 Correlation between mass loss and strength of the board heat treated at $160{ }^{\circ} \mathrm{C}$

Slika 5. Korelacija gubitka mase i čvrstoće ploče toplinski obrađene pri $160^{\circ} \mathrm{C}$
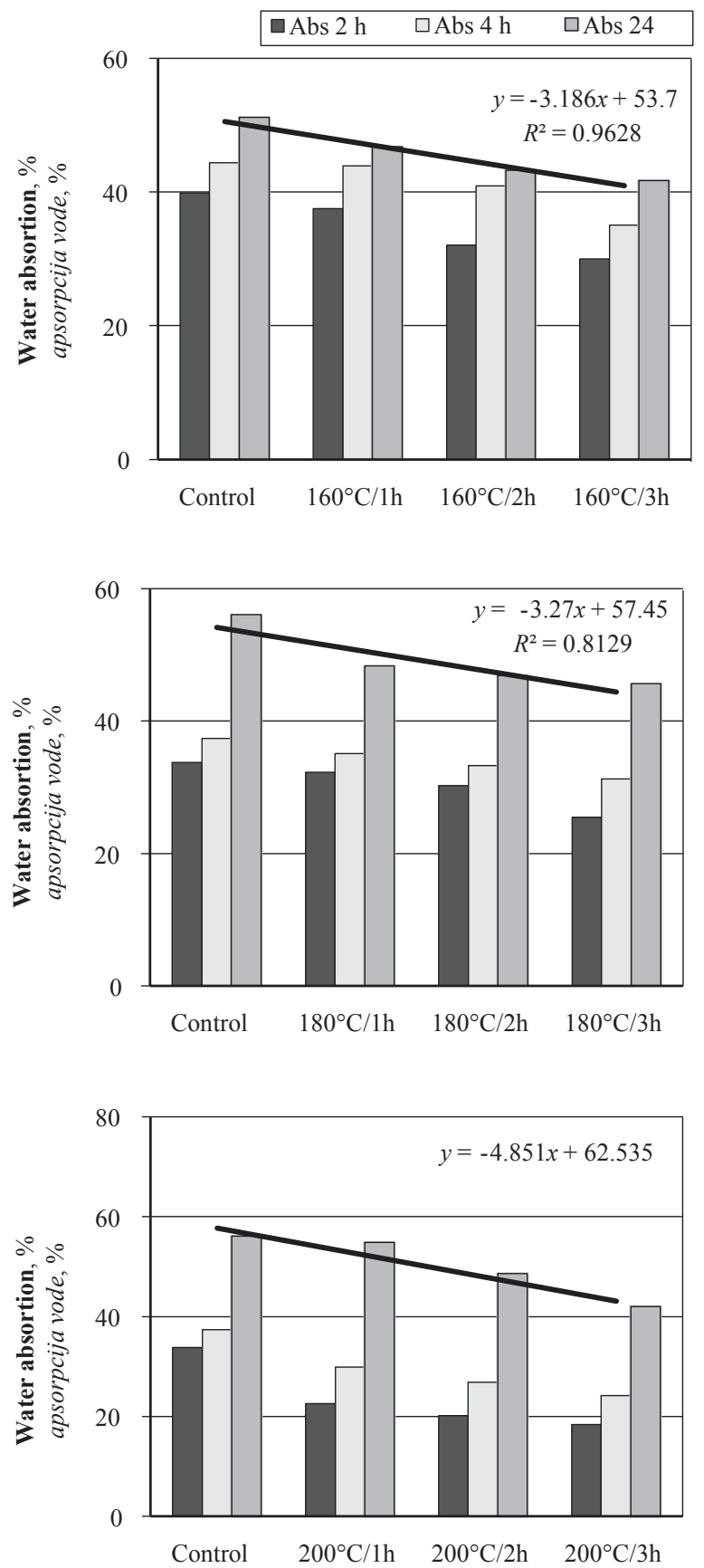

increase of the heat treatment. For example, values of $2 \mathrm{~h} / \mathrm{TS}$ for the samples treated at $160{ }^{\circ} \mathrm{C}$ for 1,2 , and $3 \mathrm{~h}$ were reduced by $2.51 \%, 8.69 \%, 30.35 \%$, respectively.

\section{CONCLUSIONS \\ 4. ZAKLJUČAK}

1. The mass loss increased with the increase of heat treatment duration and temperature. The maximum loss of strength was determined as $10.68 \%$ for the samples treated at $200{ }^{\circ} \mathrm{C}$ for $3 \mathrm{~h}$ heat exposure.

2. The modulus of rupture resistance was significantly reduced. The maximum loss of resistance was found to be $56.6 \%$ at $200{ }^{\circ} \mathrm{C}$ and $3 \mathrm{~h}$ heat treated test specimens.
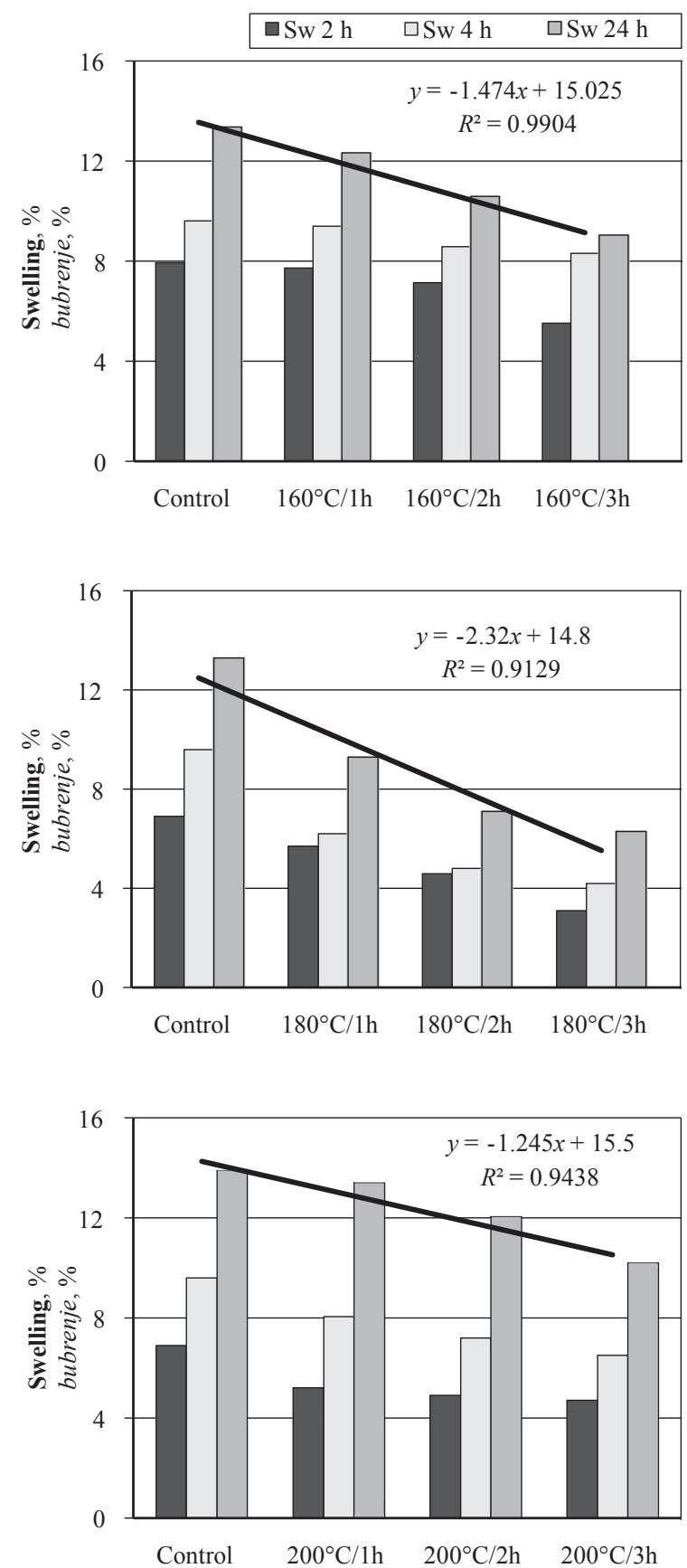

Figure 6 Water absorption and thickness swelling of the treated beech board

Slika 6. Apsorpcija vode i bubrenje toplinski obrađenih ploča od bukovine 
3. The Brinell hardness was reduced due to the increase of heat treatment duration and temperature, but such decrease of about $40 \%$ in test samples treated at 200 for $3 \mathrm{~h}$ was lower than the one obtained for MOR.

4. After being immersed in water for $2 \mathrm{~h}$, water absorption and thickness swelling were positively affected and a significant decrease was detected. The reduction in water absorption and thickness swelling were determined to be $70 \%$ and $60 \%$, respectively, for the samples treated at $200{ }^{\circ} \mathrm{C}$ for $3 \mathrm{~h}$ when compared to the control samples.

5. The heat treatment decreased the beech plywood density by $11 \%$ and the strength to bending resistance by $57 \%$.

6. These beech plywood boards cannot be used for high stress support in construction.

\section{REFERENCES}

\section{LITERATURA}

1. Arruda, L.; Del Menezzi, C., 2016: Properties of a Laminated Wood Composite Produced with Thermo-mechanically Treated Veneers. Advances in Materials Science and Engineering. ID 8458065: 1-9. Hindawi Publishing Corporation. https://doi.org/10.1155/2016/8458065.

2. Batidzirai, B.; Mignot A. P. R.; Schakel, W. B.; Junginger, H. M.; Faaij, A. P. C., 2013: Biomass torrefaction technology: Techno-economic status and future prospects. Energy, 62: 162-214. https://doi.org/10.1016/j.energy.2013.09.035.

3. Bekhta, P.; Niemz, P., 2003: Effect of High Temperature on the Change in Color, Dimensional Stability and Mechanical Properties of Spruce Wood. Holzforschung, 57 (5): 539-546. https://doi.org/10.1515/HF.2003.080.

4. Chen, W. H.; Cheng, W. Y.; Lu, K. M.; Wuang, Y. P., 2011: An Evaluation on Improvement of Pulverized Biomass Property for Solid through Torrefaction. Applied Energy, 11: 3636-3644. https://doi.org/10.1016/j.apenergy.2011.03.040.

5. Chen, W. H.; Ye, S. C.; Sheen, H. K., 2012: Hydroheat Carbonization of Sugarcane Bagasse via Wet Torrefaction in Association with Microwave Heating. Bioresource Technology, 118: 195-203. https://doi.org/10.1016/j.biortech.2012.04.101.

6. Chen, D.; Zhou, J.; Zhang, Q.; Zhu, X.; Lu, Q., 2014: Upgrading of Rice Husk by Torrefaction and its Influence on the Fuel Properties. BioResources, 9 (4): 5895-5905. https://doi.org/10.15376/biores.9.4.5893-5905.

7. Demirbas, A., 2001: Biomass Resource Facilities and Biomass Conversion Processing for Fuels and Chemicals. Energy Conversation and Management, 42 (11): 1357-1378. https://doi.org/10.1016/S0196-8904(00)00137-0.

8. Gavrilescu, D., 2008: Energy from Biomass in Pulp and Paper Mills. Environmental Engineering Management Journal, 7(5): 537-546. https://doi.org/10.30638/eemj.2008.077.

9. Feher, S.; Kolman, S.; Borcsok, Z.; Taschner, R., 2014: Modification of Hardwood Veneers by Heat Treatment for Enhanced Colors. BioResources, 9(2): 3456-3465. https://doi.org/10.30638/eemj.2008.077.

10. Jehlickova, B.; Morris, R., 2007: Effectiveness of Policy Instruments for Supporting the Use of Waste Wood as a Renewable Energy Resource in the Czech Republic. Energy Policy, 35(1): 577-585.

https://doi.org/10.1016/j.enpol.2005.12.024.
11. Kastanaki, E.; Vamvuka, D., 2005: Comparative Reactivity and Kinetic Study on the Combustion of Coal-biomass Char Blends. Fuel, 85 (9): 1186-1193. https://10.1016/j.fuel.2005.11.004.

12. Lovrić, A.; Zdravković, V.; Furtula, M., 2014: Influence of heat modification on color of poplar (Populus X Euramericana) rotary cut veneer. Wood Research, 59 (2): 661-670.

13. Lundborg, A., 1998: A Sustainable Forest Fuel System in Sweden. Biomass and Bioenergy, 15 (4-5): 399-406. https://doi.org/10.1016/S0961-9534(98)00046-4.

14. Murata, K.; Watanabe, Y.; Nakano, T., 2013: Effect of Heat Treatment of Veneer on Formaldehyde Emission of Poplar Plywood. Materials, 6: 410-420. https://doi.org/10.3390/ma6020410.

15. Nazerian, M.; Ghalehno, M. D., 2011: Physical and Mechanical Properties of Laminated Veneer Lumber Manufactured by Poplar Veneer. Journal of Agricultural Science and Technology, A1: 1040-1045.

16. Nazerian, M.; Ghalehno, M. D.; Kashkooli, X., 2011: Effect of Wood Species, amount of juvenile wood and heat treatment on mechanical and physical properties of Laminated Veneer Lumber. Journal of Applied Sciences, 11 (6): 980-987. https://doi.org/10.3923/jas.2011.980.987.

17. Omer, A. M., 2012: Biomass energy resources utilization and waste management. Agricultural Sciences, 3 (1): 124-145. https://doi.org/10.4236/as.2012.31016.

18. Percin, O.; Peker, H.; Atilgan, A., 2016: The effect of heat treatment on the some physical and mechanical properties of beech (Fagus Orientalis Lipsky) wood. Wood Research, 61 (3): 443-456.

19. Prasertsan, S.; Sajakulnukit, B., 2006: Biomass and Bioenergy in Thailand: Potential, Opportunity and Barriers. Renew Energy, 31 (5): 599-610. https://doi.org/10.1016/j.renene.2005.08.005.

20. Salca, E. A.; Kobori, H.; Inagaki, T.; Kojima, Y.; Suzuki S., 2016: Effect of heat treatment on color changes of black alder and beech veneers. Journal of Wood Science, 62: 297-304. https://doi.org/10.1007/s10086-016-1558-3.

21. Shulga, G.; Betkers, T.; Brovkina, J.; Aniskevicha, O.; Ozolinš, J., 2008: Relationship between Composition of the Lignin-based Interpolymer Complex and its Structuring Ability. Environmental Engineering and Management Journal, 7 (4): 397-400.

22. Tabarés, J. L. M.; Ortiz, L.; Granada, E.; Viar, F. P., 2000: Feasibility Study of Energy Use for Densificated Lignocellulosic Material (Briquettes). Fuel, 79 (10): 12291237. https://doi.org/10.1016/S0016-2361(99)00256-2.

23. Thompson, D.; Kozak, R.; Evans, P., 2005: Thermal modification of color in red alder veneer. Effects of temperature, heating time, and wood type. Wood and Fiber Science, 37 (4): 653-661.

24. Uslu, A.; Faaij, A. P. C.; Bergman, P. C. A., 2008: Pretreatment technologies and their effect on international bioenergy supply chain logistics. Techno-economic evaluation of torrefaction, fast pyrolysis and pelletisation. Energy, 33: 1206-1223. https://doi.org/10.1016/j.energy.2008.03.007.

25. Vilcek, J., 2013: Bioenergetic potential of agricultural soils in Slovakia. Biomass and Bioenergy, 56: 53-61. https://doi.org/10.1016/j.biombioe.2013.04.030.

26. Wang, G. J.; Luo, Y. H.; Deng, J.; Kuang, J. H.; Zhang, Y. L., 2011: Pretreatment of biomass by torrefaction. Chinese Science Bulletin, 56 (14): 1442-1448. https://doi.org/10.1007/s11434-010-4143-y.

27. Windeisen, E.; Bächle, H.; Zimmer, B.; Wegener, G., 2009: Relations between chemical changes and mechanical properties of heatly treated wood. Holzforschung, 63: 773-778. https://doi.org/10.1515/HF.2009.084. 
... Lunguleasa, Ayrilmis, Spirchez, Özdemir: Investigation of the Effects of Heat Treatment ...

28. Zdravković, V.; Lovrić, A.; Stanković, B., 2013: Dimensional Stability of Plywood Panels Made from Heatly Modified Poplar Veneers in the Conditions of Variable Air Humidity. Drvna industrija, 64 (3): 175-181. https://doi.org/10.5552/drind.2013.1223.

29. ${ }^{* * *}$ CEN/TS 15679,2007 : Heat modified timber - definitions and characteristics. European Committee for Standardization (CEN).

30. ***EN 1534, 2000: Wood and parquet flooring. Determination of resistance to indentation (Brinell) - Test method. European Committee for Standardization.

31. ***EN 317, 1993: Particleboards and fiberboards. Determination of swelling in thickness after immersion in water. European Committee for Standardization (CEN).

32. ***EN 323, 1993: Wood-based panels. Determination of density. European Committee for Standardization.
33. ${ }^{* * *}$ EN 310, 2000: Wood-based panels. Determination of modulus of elasticity in bending and of bending strength. European Committee for Standardization.

\section{Corresponding address:}

Assist. Prof. FERHAT ÖZDEMIR, Ph.D.

Department of Forest Industry Engineering Faculty of Forestry, Kahramanmaraş Sütçü Imam University 46100 Kahramanmaraş, TURKEY e-mail: ferhatozd@hotmail.com 